\title{
Influence of School Climate on Teachers Morale in Public Secondary Schools in Delta State
}

\author{
Obiajulu Chinyelum Eboka (PhD) \\ National Open University of Nigeria, (Asaba Study Center), Delta State, Nigeria
}

\begin{abstract}
The study investigated the influence of school climate on the morale of secondary school teachers in Delta School. Two research questions and two null hypotheses guided the study. The design for the study is the ex-post facto research design. Two thousand five hundred and six $(2,506)$ in seventy-two public secondary schools were selected through simple random sampling technique. The Organizational Climate Description Questionnaire $(O C D Q-R S)$ and the Purdue Teacher Opinionnaire are standardized instruments adapted to obtain information on secondary school climate and teacher morale respectively. Mean and standard deviation were used in answering the three research questions while the Step-wise Multiple Regressions was the statistical tool used to test the research hypotheses at 0.05 level of significance. The findings revealed that a positive climate prevails in most public secondary schools in Delta State than a negative school climate. Furthermore, a positive school climate in secondary schools influenced teacher morale resulting in a considerably high level of morale for teacher rapport with principal, rapport amongst teachers, satisfaction with teaching and teacher status while a moderate level of teacher morale was the result for teacher load. However, it was noted that organizational climate did not have a statistically significant influence on teacher morale.
\end{abstract}

Key Words: School Climate, Morale, Teacher Morale, Secondary School

\section{Introduction}

Teachers work at all levels of education, be it primary, secondary or at the tertiary level. Teachers are the focal point in any educational system. Many view teachers as a nation's greatest asset and also as the catalyst that execute the curriculum (Mgbodile, 2004, Osman, Halim \& Meerah, 2006). Teachers are seen too as the focus for human resource development as well as the major agents for the fulfillment and actualization of the curriculum (Okolo, Haruna \& Oguche, 2013). The quality of education hinges on the quality of teachers as a result teachers are critical to the success of any educational system. Supporting this view, Ukeje (1983) states that teachers are the hub of the educational system. Therefore, Nigeria as a nation cannot afford to neglect its teachers, having acknowledged education as a tool to attain the much desired rapid social and economic development (FRN, 2004). For teachers to play their roles and fulfill their responsibilities to realize the purpose of education in national development it is of utmost importance that teachers are provided with a conducive school climate to perform their duties. Consequently, secondary school leadership (principals) should strive to ensure that the conducive school climate needed to achieve educational goals and objectives in secondary schools is in place.

\subsection{The Concept of School Climate}

Climate generally is the nature of the work environment which is perceived by people as threatening or relaxed, supportive or non-supportive to carry out their work (Tetteh, 1999). Specifically, school climate is a relatively enduring quality of the school environment that is experienced by people within that environment, affects their behaviour and centres on the collective perceptions of behaviour in the school (Hoy, 2003). In this study, climate of a school is considered as that environment or internal quality of a school that is a product of interpersonal relationships both in the formal and informal group, which affects all its activities and can be observed by people within and outside the school. This environment is where the principal, teachers and students converge in a formal relationship to achieve educational goals and objectives (Achiune, 1998). The school environment has its own attitudes, beliefs, norms and values, which constitute a peculiar climate. The climate of a school is a product of human interactions within the school (Peretomode, 1991). It is also perceived as those internal characteristics both physical and psychological that distinguish one school from another and influence the behaviour of both staff and students (Hoy, kottkamp \& Tarter, 2000). These characteristics form the personality of the school just as personality is to an individual.

\subsection{Types of School Climate}

Halpin and Croft (as cited in Peretomode, 1991) proposed six climate types, which are the autonomous, closed, controlled, familiar, open and paternal climate. Hoy, Kottkamp \& Tarter also proposed four climate types namely; the open, engaged, disengaged and closed climate. This study will be concerned with the closed 
and open climate in secondary schools which appear to be two extremes of the organizational climate type continuum. In the closed climate, the principal and teachers do not work towards the achievement of educational goals or personal needs satisfaction (Eneasator, 1997). A positive and open climate as stated by Osterman (2000) is a safe, caring, participatory and responsive environment that fosters great attachment to the school as well as provides a foundation for social, emotional and academic learning. Freisberg (1998) believes that the climate of a school can be "a positive influence on the health of the learning environment or a significant barrier to learning" (p. 22). School climate is a phenomenon that has been researched into for many years and is still being examined and redefined because of its significant influences on educational outcomes especially on teacher morale (Lumsden, 1998 \& Marshall, 2002).

\subsection{The Concept of Teacher Morale}

Teacher morale is the professional interest and enthusiasm teachers display towards the achievement of individual and group goals in a given job situation (Bentley \& Rempel, 1980). For the purpose of the study, teacher morale is considered as the mental and emotional attitude of teachers towards their task that has a direct effect on the enthusiasm, confidence, loyalty and interest displayed in performing their job. Teacher morale assists in establishing the character of a school and it is one of the factors that determines whether a school functions at its best or not (Ellenberg, 1972). This makes it important for leadership in secondary schools to encourage teacher participation, commitment and co-operation in school activities by providing a supportive climate. In such a healthy school climate, teachers may be more willing to perform any assignment given to them with zeal and dedication. Therefore, teacher morale may possibly be high in a school environment that are healthy and supportive. Teacher morale is examined with respect to five morale factors as stated by Bentley and Rempel which are teacher rapport with principal, rapport amongst teachers, satisfaction with teaching, teacher status and teacher load for their relevance in the Nigerian educational system .

\subsection{Factors Affecting Teacher Morale}

Certain factors have been perceived to affect teacher morale. These factors include a healthy school environment, teachers' perception of students and student learning, administrative support and leadership, and favourable workplace conditions (Lumsden, 1998). A healthy school climate is related to high teacher morale where a positive climate exists according to Hoy and Miskel (1987). Mullins (1999) believes that the climate created by leadership in organizations has a significant influence on the motivation and behaviour of employees. Stress has also been found to be a factor that can affect the morale of teachers. According to Stenlund (1995), stress can result in emotional and physical fatigue which can lead to a reduction in work motivation, involvement and satisfaction. A stressed feeling, therefore, can result in the erosion of a teacher's interest, sense of humour and enthusiasm.

\subsection{Effect of Low Teacher Morale}

Low teacher morale is evident when there is little interest and enthusiasm for the job while high morale is obvious when teachers have interest in and display enthusiasm for the job (Bentley \& Rempel, 1980). Teachers with low morale see their professional lives as having little meaning out of frustration and the inability to change the adverse state of affairs (Koerner, 1990). Strickland (as cited in Houchard, 2005) identified ten factors that may lead to low teacher morale as lack of relief from student contact on a school day, overwhelming clerical duties, lack of support and co-operation from school administration, inadequate school facilities, lack of co-operation with staff, excessive teaching loads, low salary, reduced parental interest and co-operation, student discipline problems and lack of working equipment and supplies. Low level of teacher morale according to Lumsden (1998) can lead to a decrease in teacher productivity, loss of concern for students, alienation from colleagues, depression, and increased rate of sickness resulting in absenteeism on some workdays, general fatigue and burnout.

\subsection{Effect of High Teacher Morale}

High teacher morale is associated with intrinsic rewards such as pupil achievement, changing attitudes of students and behaviours in a positive way, recognition from others, mastery and self-growth and positive relationships (Dinham, 1994). According to Washington and Watson (1976) teacher's high morale can be perceived through the display of several behaviours. These high teacher morale behaviours are demonstrated when teachers look forward to going to work in the morning and are not in a hurry to leave work at the end of the school day, teachers who show concern as to the direction of school programmes and participate actively in school functions, committees and organizations, perform various school tasks above and beyond stated duties as well as derive satisfaction from being a member of the school and teaching profession. More so, a high morale is seen in teachers who support the school, its goals and philosophy and are actively engaged in improving school community relations. Napier (as cited in Hourchard, 2005) associated high teacher morale with teachers being 
appreciated by the school administration, the administrators confidence in teachers competence, the support of the administration when dealing with student discipline problems, teacher participation in the development of school policies, the provision of adequate equipment, teaching supplies and facilities, appropriate teaching loads and assignments, equitable distribution of curricular duties, in-service training and staff development and job security.

The morale of teachers has far-reaching effects not only on students' learning but also on the health of the organization and on the health of teachers (Mendel, 1987). According to Ellenberg (1972), teacher morale goes beyond affecting just teacher productivity or student achievement. Most importantly, teacher morale assists in establishing the character of the school. In addition, teacher morale is considered one of the factors that determine whether a school functions at its best or not. Most public secondary schools in Delta State are yet to be given the attention they deserve considering the current challenges facing this level of education. Several research findings reveal a lack of teaching resources and infrastructure such as science laboratories, wellequipped libraries and even the existence of inadequate classrooms resulting in large class size in public secondary schools (Oriafo, 2002, Ajaja, 2009 \& Eboka, 2015). This poses as a great hindrance on effective teaching, learning and skills development in secondary education. Can the resultant school climate provide a suitable learning environment that will influence teacher morale positively? Will this school climate support enhanced teaching and learning? The purpose of this study is to determine the influence of school climate on the morale of teachers in public secondary schools. It is against this background that the researcher focused on examining the influence of school climate on secondary school teacher's morale.

\subsection{Purpose of the Study}

The main aim of the study is to examine the influence of school climate on the morale of secondary school teachers in Delta State. Specifically, the study seeks to

1. Determine the type of school climate that exists in public secondary schools.

2. Examine the influence of organizational climate on teacher morale.

\subsection{Research Questions}

1. What type of school climate exists in public secondary schools?

2. What is the influence of organizational climate on teacher morale?

\subsection{Research Hypothesis}

The following hypotheses tested at .05 level of significance guided the study:

HO 1 There is no significant difference between the influence of an positive and negative school climate on teacher morale.

\section{Methodology}

The design adopted for the study is the ex-post facto design. The study was carried out in Delta State which comprises of three senatorial districts namely Delta North, Delta Central and Delta South with twentyfive (25) Local Government Areas. The population of the study consists of three hundred and sixty-seven principals (367) and eleven thousand, four hundred and two $(11,402)$ teachers in three hundred and sixty-seven (367) public secondary schools in the three senatorial districts in Delta State. Using the simple random sampling technique, seventy-two (72) principals and two thousand, five hundred and six $(2,506)$ teachers in seventy-two (72) public secondary schools were selected as the sample of the study. The seventy-two (72) principals comprised of forty-one (41) female and thirty-one (31) male principals. Two standardized research instruments namely the Organizational Climate Description Questionnaire (OCDQ-RS) and the Purdue Teacher Opinionnaire (PTO) were used to collect the data for the study. The Organizational Climate Description Questionnaire (OCDQ-RS) utilized in the study is a 25 item instrument designed to measure secondary school climate (Hoy, Tarter and Kottkamp, 2000). The OCDQ-RS has five different dimensions that measure the behaviour of teachers and principals. Two dimensions of the OCDQ describe principal behaviours that are supportive and directive while three dimensions describe teacher behaviours which are engaged, frustrated and intimate. Purdue Teacher Opininnaire (PTO) is a 32 item questionnaire made up of five clusters namely teacher rapport with principal, Rapport amongst teachers, Satisfaction with teaching, Teacher status and Teacher Load. The response formats for all the items in the questionnaire was Disagree, Probably Disagree, Probably Agree and Agree which were rated 1, 2, 3, 4 and 5 respectively. Research experts in the Department of Educational Foundations and two experts in the Department of Measurement and Evaluation in the University of Nigeria, Nsukka validated the research instruments. The Cronbach -Alpha method was used to determine the reliability of the instruments used in the study. The overall reliability coefficient obtained for the Multifactor Leadership Questionnaire (MLQ) was 0.84 and 0.88 for the Purdue Teacher Opinionnaire (PTO). Out of one thousand five hundred questionnaires administered, only nine hundred and forty (940) of them were useful for the study. The simple descriptive statistics of mean, standard deviation and percentage were used to answer the research questions while the t-test was the statistical tool used to address the research hypotheses at 0.05 levels of 
significance. To determine the type of principal's leadership style, any principal that scored above the cluster mean of 2.5 for transactional leadership items was considered a transactional leader while any principal that scored above the criterion mean of 2.5 for transformational leadership style items was considered a transformational principal. The following guidelines were used to interpret the mean scores of teacher morale factors in accordance with Bentley and Rempel (1980):

Table 3.1

\begin{tabular}{|c|l|}
\hline Mean Score of Teacher Morale & Interpretation \\
\hline $1.00-1.25$ & Very low Teacher Morale \\
$1.26-1.99$ & Moderately low Teacher Morale \\
$2.00-2.75$ & Moderate Teacher Morale \\
$2.76-3.49$ & Moderately High Teacher Morale \\
$3.50-4.00$ & High Teacher Morale \\
\hline
\end{tabular}

\section{Research Question One}

\section{Results}

What type of organizational climate exists in public secondary schools?

Table 4.1: Mean and Standard Deviation for Secondary Schools with a Positive and Negative

Climate.

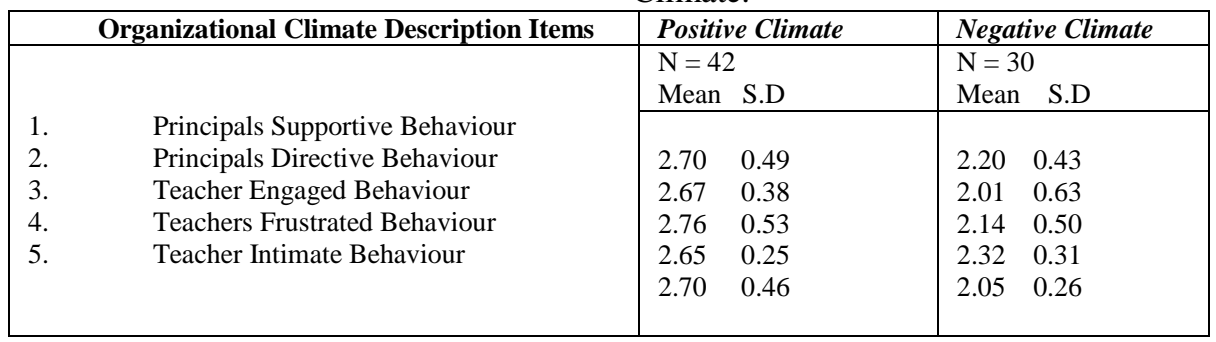

Data on table 1 shows the mean and standard deviation of organizational climate items for secondary schools in Delta State. The Organizational Climate Description Questionnaire (OCDQ-RS) measured school climate. Forty-two (42) public secondary schools were found to have an open climate while thirty (30) public secondary were found to have a closed school climate. The five dimensions of the OCDQ-RS are principals supportive behaviour, principal directive behaviours while three dimensions describe teacher behaviours which are engaged, frustrated and intimate. In the open climate, the mean scores for these five dimensions were 2.70, 2.67, 2.76, 2.65 and 2.70 respectively with standard deviation of $0.49,0.38,0.53,0.25$ and 0.46 . The mean scores for the five dimensions schools having a closed climate were 2.20, 2.01, 2.14, 2.32 and 2.05 respectively with standard deviation of $0.43,0.63,0.50,0.31$ and 0.26 respectively too.

In the positive climate, the cluster mean for the five dimensions of the OCDQ were all above the standard mean of 2.5 while the cluster mean of the various dimensions in the negative climate were all below the standard mean of 2.5. Finally, the overall mean score for the open climate was 2.70 and 2.05 for the closed climate.

\section{Research Question Two}

What is the influence of organizational climate on teacher morale?

Table 4.2: Mean and Standard Deviation of the Influence of Positive and Negative School Climate on Teacher

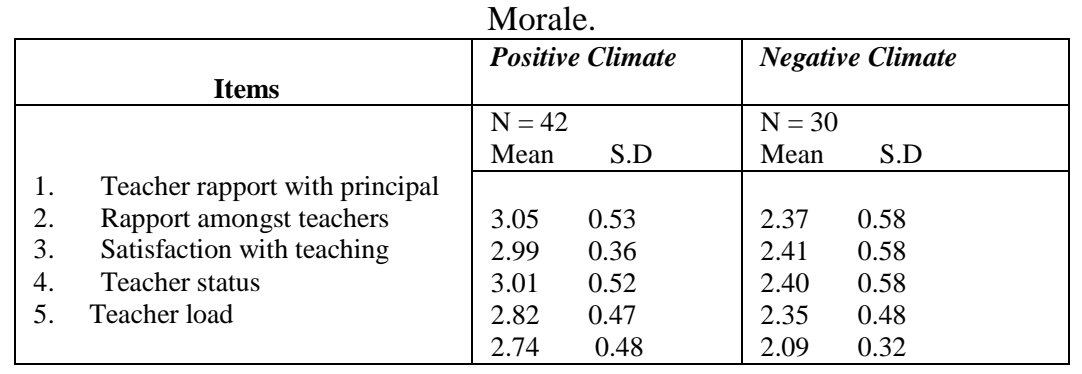

An analysis of the teacher morale factors in the positive climate showed that the cluster mean values for teacher rapport with principal was 3.05, rapport amongst teachers was 2.99, satisfaction with teaching was 3.01 , teacher status was 2.82 and teacher load was 2.74 . However, the grand mean obtained as seen on table 5 was 2.96 indicating a moderately high level of morale in the positive school climate. On the other hand, in the negative climate the cluster mean scores were 2.09 for teacher load, 2.35 for teacher status, 2.37 for teacher 
rapport with principal, 2.40 for satisfaction with teaching and 2.41 for rapport amongst teachers. These mean scores fell within the moderate level of teacher morale. The overall analysis however, suggests that the influence of the positive school climate resulted in a moderately high level of teacher morale while the influence of a negative school climate resulted only in a moderate level of teacher morale.

\section{Hypothesis One}

There is no significant difference between the mean scores of the influence of positive and negative school climate on teacher morale.

Table 3: t-test of difference between a Positive and Negative School Climate

\begin{tabular}{|l|l|l|l|l|l|l|l|l|l|}
\hline CLIMATE & MEAN & SD & N & DF & STD ERROR & T & P-VALUE & t- Table value & MEAN DIFF. \\
\hline OPEN & 2.96 & 0.44 & 32 & 70 & 0.068 & 5.74 & 0.000 & 1.96 & 0.60 \\
CLOSED & 2.35 & 0.43 & 40 & & 0.080 & & & & \\
\hline
\end{tabular}

The result of the t-test analysis in table 3 revealed that the observed difference in the mean score of open (2.96) and closed (2.35) school climate was found to be significant $(p=0.00<0.05)$ at 0.05 level of significance. Therefore, the hypothesis that there is no significant difference between an open and closed school climate was accepted. Consequently, there is a significant difference between the mean scores of the influence of open and closed climate on teacher morale.

\section{Discussion}

The findings of the study revealed that a positive climate prevails in more public secondary schools in Delta State than a negative climate. Most teachers in secondary schools with a positive climate agreed that their principals exhibited both supportive and directive behaviours. This indicated that these principals showed support for teachers and were concerned about their teachers' welfare also. This however negates the findings of Hoy, kottkamp and Tarter (2000) which stated that in an open/positive climate the principal is more supportive than directive because teachers in schools with a positive climate percieved that their principals' behaviours were both directive and supportive. Surprisingly, the score for teacher frustrated behaviour in schools with the negative climate was quite low too indicating that teachers had an indifferent attitude to work since the leadership did not appear to be effective. The negative climate was also marked by low intimacy indicating that teachers did not work together as a team or socialize together.

Furthermore, research question two revealed that a positive climate in secondary schools influenced teacher morale resulting in a considerably high level of morale for teacher rapport with principal, raport amongst teachers, satisfaction with teaching and teacher status while a moderate level of teacher morale was the result for teacher load. It was observed that the negative climate resulted in a moderate level of teacher morale for all the teacher morale factors. The results of the findings clearly showed that a positive climate results in higher influence on teacher morale than a negative climate. Therefore, a positive climate influences teacher morale better than a negative climate. This is consistent with the findings of Eneasator (1993) which states that an open climate in secondary schools has a more positive influence on teacher job-satisfaction than a closed climate. It also agrees with Freisberg (1998) who stated that a positive school climate is marked by enhanced staff performance, higher teacher morale and improved student achievement. However, it was noted that organizational climate did not have a statistically significant influence on teacher morale.

The role of a positive school climate cannot be seperated from meaningful teaching and learning because a positive climate is usually associated with positive psychological and academic outcomes for students. In such a climate there will be limited student behavioural and emotional problems such as students' involvement in cultism, bullying, indiscipline, truancy and examination malpractice rather academic performance will be enhanced because there will be meaningful teaching and learning. On the other hand, a negative climate will hinder optimal learning and development in secondary schools and encourage anti-social behaviours in students. Teacher morale can only be improved and sustained in a positive school climate. This type of climate will certainly discourage student anti-social behaviours in public secondary schools.

The results of the findings also showed that the influence of one of the teacher morale factors examined, teacher load scored the least on the level of teachers' morale when compared to other teacher morale factors. This indicates that this area needs to be addressed as it does not considerably raise the morale of teachers. This may not be unconnected with the fact that in addition to the task of teaching subject content, teachers are involved with a lot record keeping (eg. registers, diaries, lesson notes), clerical work, co-curricular load, community demands on teachers' time and also have to keep up to date professionally. This obviously dampens teachers' morale and goes a long way to affect their work performance. 


\section{Conclusion}

The findings revealed that organizational climate influences teacher morale. Specifically, a positive school climate was seen to have a greater influence on teacher morale yielding a moderately high level of teacher morale than a negative school climate. However, the influence of organizational climate on teacher morale was not found to be statistically significant. Considering the five teacher morale factors examined, teacher load gave rise to the lowest level of teacher morale.

\section{References}

[1]. Achuine, R. (1998). Further issues in school administration. (2nd Ed.). Owerri: Cajec Publication.

[2]. Ajaja, O. P. (2009). Evaluation of science teaching in secondary schools in Delta State 2- teaching of the sciences. International Journal of Education Science 1(2), 119-129.

[3]. Bentley, R.R. \& Rempel, A.M. (1980). Manual for the Purdue Teacher Opinionnaire. Indiana: The University Bookstore.

[4]. Dinham, S. (1994). Societal pressures and teaching. Paper presented to the Australian Association for research in Education Annual Conference. New Castle, England.

[5]. Eboka, O. C. (2015). Evaluation of strategies for Quality Assurance in secondary science education in Delta North Senatorial District. An unpublished Masters Dissertation, National Open University of Nigeria, Lagos.

[6]. Ellenberg, F.C. (1972). Factors affecting Teacher Morale. NASSP Bulletin, 56(12) 76

[7]. Eneasator, G.O. (1997). Organizational climate and teacher productivity. In A.N. Ndu, L.O. Ocho \& B.S. Okeke (Eds.), Dynamics of Educational Administration and Management- The Nigerian Perspective, (pp299-306). Onitsha: Meks Publishers Ltd.

[8]. Federal Republic of Nigeria (2004). The National policy on Education. 4th ed. Lagos: Nerc Press.

[9]. Freisberg, H.J. (1998). Measuring school climate: Let me count the ways. Educational Leadership, 56 (1), $22-26$.

[10]. Houchard, M.A. (2005). Principal leadership, teacher morale and student achievement in seven schools in Mitchell County, North Carolina. Unpublished doctoral dissertation, Tennessee State University, Tennessee. Retrieved from http://www. Houchard miii605f.pdf

[11]. Hoy, W.K. (2003). Organizational Climate. Retrieved from http://www.coe.Ohio- state.edu/whoy/34.

[12]. Hoy, W.K. \& Miskel, C.G. (1987). Educational Administration: Theory, Research and Practice (3 $3^{\text {rd }}$ ed.). New York: Random House.

[13]. Hoy, W.K., Kottkamp, R.B. \& Tarter, C.J (2000). Open schools/Healthyschools: Measuring school climate. Retrieved from http://www//F:On-line\%20Books.htm

[14]. Koerner, T.F. (1990). Developing staff morale. The Practitioner, 16, 4.

[15]. Lumsden, L. (1998). Teacher morale. Eric Digest, 120, p.1-2.

[16]. Retrieved from http://www.eric.uoregon.edu/pdf/digests/digest120.pdf

[17]. Marshall, L.M. (2002). Examining school climate: Defining factors

[18]. and Educational influences. Retrieved from http://wp\%202002\%20school\%20climate.pdf

[19]. Mgbodile, T.O. (2004). Instructional leadership in schools. In T.O. Mgbodile (Ed.), Fundamentals in Educational Administration and Planning, (pp 140-148). Enugu: Magnet Business Enterprise.

[20]. Mullins, L.J. (1999). Management and organisational behaviour. London: Financial Times Management.

[21]. Oriaifo, S. O. (2002). Refocusing Science and Mathematics Education in Nigeria. In

[22]. Oriaifo, S. O., Nwaokolo, P. O. \& Igborgbor, G. C., Refocusing Education in Nigeria- A Book of Readings.

[23]. Peretomode, V.T. (1991). Educational administration: Applied concepts and theoretical perspectives. Lagos: Joja Educational Research and Publications Limited.

[24]. Osterman, K.F. (2000). Students' need for belonging in the school community. Review of Educational Research, 70, 323-367.

[25]. Stenlund, K.V. (1995). Teacher perceptions across cultures: The impact of students on teacher enthusiasm and discouragement in a cross-cultural context. The Alberta Journal of Educational Research 41(2), 145-161.

[26]. Tetteh, L. (1999). Organizational climate and school proprietorship as factors in teacher effectiveness and attitudes to teaching. Unpublished doctoral dissertation, University of Nigeria, Nsukka.

[27]. Washington, R. \& Watson, H.F. (1976). Positive teacher morale: The principals' responsibility. NASSP Bulletin 60 (399), $4-6$. 